\title{
BIOMETEOROLOGINĖS PROGNOZĖS KAIP ADAPTACIJOS PRIEMONE் KLIMATO KAITOS KONTEKSTE
}

\author{
Ieva Nariūnaité ${ }^{1}$, Judita Liukaityte $\dot{2}^{2}$ \\ Vilniaus universitetas ${ }^{1}$, Lietuvos hidrometeorologijos tarnyba prie Aplinkos ministerijos ${ }^{2}$

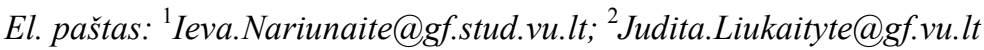

\begin{abstract}
Anotacija. Klimato kaitos ir žmogaus tarpusavio ryšys yra neabejotinai stiprus, jis turi nesustabdomą tąsą laike, kuri lemia vis didesnę fizinę ar psichologinę žmogaus reakciją. Biometeorologija gerai perteikia jųdviejų sąsajas ir apibūdina esamą bei būsimą klimato kaitos poveiki, žmogaus pojūčius tokioje aplinkoje. Tad šiame darbe aptariamos Lietuvoje plètojamos biometeorologinès prognozès, jų sudarymo principai, galimybès bei nauda prisitaikant prie klimato kaitos.
\end{abstract}

Reikšminiai žodžiai: biometeorologinès prognozès, klimato kaita, adaptacija.

\section{Ivadas}

Klimatas ir orai visuomet turejo didžiuli poveiki žmogaus sveikatai bei savijautai. Besikeičiantis klimatas keičia daugelio ekosistemų funkcionavimą, augalų ir gyvūnų rūšių buveines, daro nemenką itaką žmonijos sveikatai (McMichael et al. 2003; Bukantis et al. 2007).

Apie iqvairiu gamtos elementų ir oro sąlygu poveiki žmogaus sveikatai jau buvo žinoma labai seniai. Pirmasis šia tema išleistas darbas yra Hipokrato veikalas „Apie orą, vandeni ir vietovę". Nemažai informacijos apie tai aptinkama ir liaudies medicinoje. Tačiau šios srities aukso amžiumi galima vadinti XX a. 3-6 dešimtmečius, tai buvo medicininès meteorologijos klestejjimo laikas (Sargent II 1982). Paskutiniais dešimtmečiais pradejjus vis dažniau kalbèti apie besikeičianti klimatą ir kaitos poveiki žmogui, vèl pagausèjo tyrimų šioje srityje. Visos klimato sistemos pokyčiai skatina vis labiau isigilinti i tiesiogini (ar netiesiogini) ekstremalių reiškinių poveiki aplinkai bei žmonių sveikatai.

Pasak Valstybinio aplinkos sveikatos centro (VASC 2009), kiekvienas organizmas turi genetinę informacija, imuninę sistemą ir yra prisitaikęs prie tam tikru klimato sąlygų, o joms kintant prie jų privalo adaptuotis. Deja, išaugęs ligu ir mirčiu skaičius (dèl ekstremalių klimato reiškiniu padidejjimo, karščio bei šalčio bangu poveikio ir sustiprejjusios ultravioletinès radiacijos), psichikos sutrikimų skaičius (dẻl padažnejjusių ir sustiprejjusių gamtinių stichiju) - klimato kaitos padarinys. Poveikis sveikatai gali būti ir netiesioginis, pasireiškiantis užkrečiamujų ligu plitimu, ligu ir mirčių skaičiaus didèjimu dèl oro taršos, žiedadulkiu sezoniškumo ir kraujasiurbių vabzdžių bei erkiu platinamų ligų pokyčių, ekstremalių reiškinių (potvynių, vejo audrų, sausrų, karščio bangu) poveikio.

Augant populiacijai, pavojus sveikatai stipreja, nors iš dalies tai suteikia galimybę fiziškai, psichologiškai ir finansiškai pasiruošti ir vèliau tinkamai reaguoti i tam tikrą ekstremalų orų reiškini (Epidemiology 2008). Tad vienintelis būdas apsisaugoti ar bent sušvelninti klimato kaitos poveiki sveikatai - laiku suteikti reikalingą informaciją apie būsimus orų ir meteorologinius parametrus, lemiančius žmonių savijautą.

Šio darbo tikslas - apžvelgti Lietuvoje sudaromas biometeorologines prognozes, jų reikalingumą ir pagalbą prisitaikyti prie klimato kaitos.

\section{Duomenys ir darbo metodika}

Gerejant supratimui apie klimato ir oru poveiki žmogui, šiai sričiai vis daugiau dèmesio skiriama ir nacionalinėse oru tarnybose. Daugelis jų teikia informaciją ir prognozes, kaip prisitaikyti prie nepalankiu sveikatai meteorologiniu sąlygu ir sumažinti aplinkos veikimą bei keliamą stresą (WMO 2004).

Biometeorologinèms prognozėms, kurios yra skelbiamos įvairiose tarnybose, priskiriama:

- terminių indeksu prognozès;

- ultravioletinès spinduliuotès prognozės;

- medicininès meteorologinès prognozès;

- oro užterštumo prognozès;

- žiedadulkių kiekio ore prognozès.

Iki $2008 \mathrm{~m}$. iš visų plačiai pasaulyje naudojamu biometeorologiniu prognozių tik ultravioletinès radiacijos indekso prognozė buvo skelbiama Lietuvos hidrometeo- 
rologijos tarnyboje prie Aplinkos ministerijos (LHMT). Ir tik praejjusiais metais pradèta sudarinèti karščio ir vejjo žvarbumo indeksų prognozes, šios prognozių grupès ir bus pristatytos šiame darbe.

Skaičiuojant naudoti LHMT meteorologijos stočiu 1993-2006 m. duomenys.

Darbe naudojamas karščio indeksas - „Humidex“ $\left({ }^{\circ} \mathrm{C}\right)$ :

Humidex $=\boldsymbol{T}+5 / 9 \times(e-10)$,

čia: $T$ - oro temperatūra, ${ }^{\circ} \mathrm{C} ; e-$ vandens garų slègis $(\mathrm{hPa})$, apskaičiuojamas pagal formulę:

$$
\boldsymbol{e}=\left(6,112 \times 10^{\frac{7,5 \times \boldsymbol{T}}{237,7+\boldsymbol{T}}}\right) \frac{\boldsymbol{f}}{100}
$$

čia: $f$ - santykinis oro drègnis, \%. Ši indeksą 1979 m. Kanados atmosferos aplinkos centre sukūrè J. Mastertonas ir F. Ričardsonas (Masterton, Richardson 1979). LHMT, remdamasi šiuo indeksu, sudarinejja karščio indekso prognozes.

Vejjo žvarbumo indeksas (WCT) nusako temperatūros ir vèjo poveiki žmonių komfortui:

$\boldsymbol{W C T}=13,13+0,62 \times \boldsymbol{T}-13,95 \times \boldsymbol{V}_{10 \mathrm{~m}}^{0.16}+0,486 \times \boldsymbol{T} \times \boldsymbol{V}_{10 \mathrm{~m}}^{0.16}$,

čia: $T$ - oro temperatūra, ${ }^{\circ} \mathrm{C} ; V$ - vejjo stiprumas dešimties metrų aukštyje (Massen 2001).

Skaičiuojant ultravioletinès saulès spinduliuotès indeksą (UVI) naudojami Kauno meteorologijos stoties 2001-2005 m. eriteminès radiacijos paros maksimumo duomenys.

\section{Terminių indeksų prognozès}

Aukštos oro temperatūros daro poveiki žmonių sveikatai, o dažnai tampa ir mirties priežastimi. O labai karštos dienos ir neretai karščio bangu metu tvankios naktys sukelia kai kurias ligas ar jų paūmėjimą (Kirch et al. 2005; Dessai 2002; Gosling et al. 2007).

Tik po 2003 m. buvusios karščio bangos daugelis Europos šalių ėmèsi efektyvios politikos, kaip elgtis karščio bangu metu. Prieita prie vieningos nuomonès, kad Europos šalyse reikalinga bendra karščio perspejjimo sistema. Šiuo metu daugelis šaliu jau turi savo perspejjimo sistemas, kurios skelbia karščio pavojų. Ir dažniausiai remiasi aukščiausios ar vidutinès temperatūros terminių indeksų reikšmėmis (WHO 2004).

Terminis žmogaus komfortas priklauso nuo keleto meteorologiniu parametrų: oro temperatūros ir drègnumo, vejjo greičio, trumpabangès saulès bei žmogu supančio paklotinio paviršiaus ilgabangès spinduliuotès intensyvumo. Žmonių jaučiamam karščio diskomfortui apibūdinti pasaulyje sukurta nemažai teorinių ir empirinių indeksų, kurie i skaičiavimus įtraukia pavienius meteorologinius elementas ar jų kompleksus. Daugelis jų jau aptarti ivairiu autoriu darbuose (Matzarakis et al. 2004, 2007; Unger 1999; Höppe 1999).

Terminis šiltojo laikotarpio komfortas dažniausiai skaičiuojamas naudojant oro temperatūrą ir drègnumą, o žiemos - oro temperatūrą bei vèjo greitị. Tai svarbiausi parametrai, lemiantys termini žmogaus diskomfortą skirtingu metų laiku. Remiantis šiais indeksais, jau šiais metais pradedama skelbti ir terminių indeksų prognozes Lietuvoje.

Šiltuoju sezonu skelbiama karščio indekso prognozè. Indeksas apskaičiuojamas vidudieniui esant aukščiausiai temperatūrai ir tuo metu esančių santykinio oro drègnumo reikšmių.

Šio indekso naudojimo galimybès J. Liukaitytès ir E. Rimkaus (2008) buvo izvertintos kaip tinkamos naudoti Lietuvoje.

Maksimalios „Humidex“ indekso reikšmès Lietuvos teritorijoje fiksuojamos paskutinę liepos dekadą ir rugpjūčio pradžioje. Jos didžiausios Panevėžyje, kur paskutini liepos penkiadieni vidutinè dienos matavimų indekso reikšmè siekia $26,1{ }^{\circ} \mathrm{C}$. Pajūryje dèl vėsinančio Baltijos jūros poveikio jos yra kiek mažesnès. Tyrimai parodè, kad karščio diskomfortą sukelianti reikšmė viršijama 22$31 \%$ visų vasaros dienų.

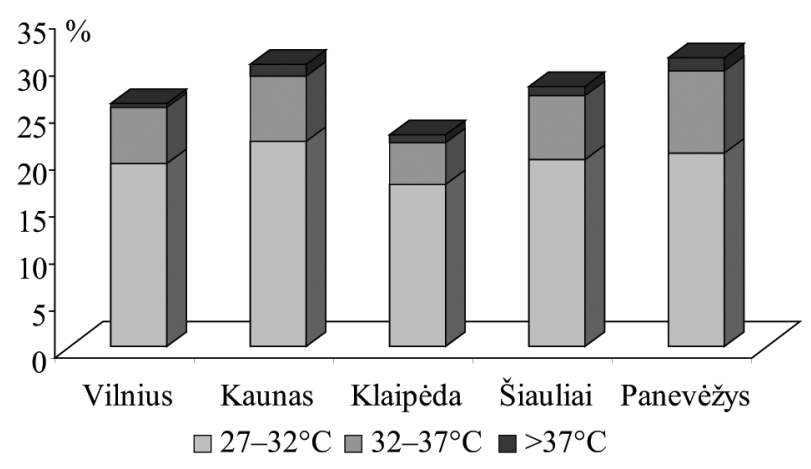

1 pav. Dienų, kai „Humidex“ indekso reikšmè viršijo $27^{\circ} \mathrm{C}$, skaičius (\%) vasaros mènesiais (1993-2006 m.)

Fig. 1. Number of days with daily "Humidex" index maximum above $27^{\circ} \mathrm{C}$ in summer time 1993-2006

Remiantis šia prognoze, apie artejančią karščio bangą galima pradèti informuoti žmones, pateikti jiems jutiminès temperatūros prognozę (kokią temperatūrą jie jaus išèję i lauką ir koks bus sukeliamas poveikis sveikatai). 
Šaltuoju metų laiku (lapkričio-kovo mėnesiais) pradèta skelbti vẻjo žvarbumo prognozè, informuojanti apie žmogaus jaučiamą temperatūrą esant žemoms oro temperatūros reikšmèms ir stipresnio nei $1,5 \mathrm{~m} / \mathrm{s}$ vèjo. Tai paprastas indeksas, apimantis tik šiuos du parametrus, tačiau vèjo stiprumas ir oro temperatūra yra pagrindiniai elementai, turintys poveikị žmogaus komfortui šaltuoju metų sezonu.

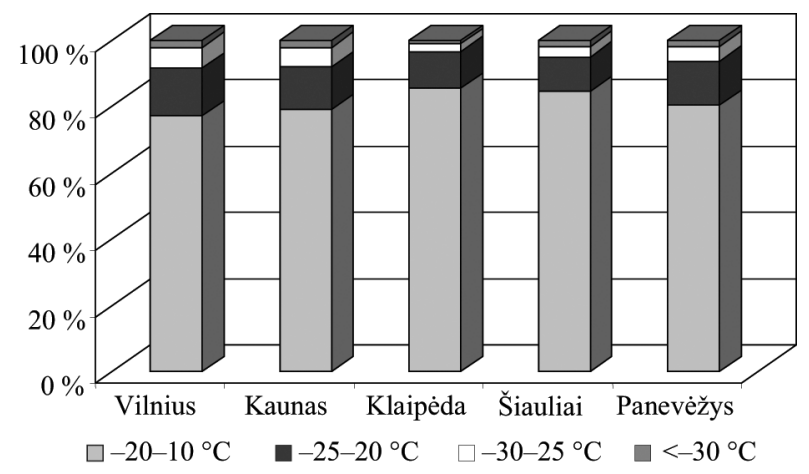

2 pav. „Vèjo žvarbumo“ reikšmiu pasiskirstymas šaltuoju metų sezonu (1993-2006 m.)

Fig. 2. "Wind chill" values in cold season 1993-2006

Kaip ir karščio indeksas, vejjo žvarbumas taip pat turi savo gradaciją. Ji apibūdina poveiki sveikatai bei nušalimo galimybę. Pavojinga riba laikoma tada, kai vejjo žvarbumo indekso reikšmė yra žemenė nei $-27{ }^{\circ} \mathrm{C}$. Prognozès yra sudaromos 30 valandų i prieki, 6 valandų intervalu.

Šiuo metu nèra atlikta tikslių tyrimų, kiek žmoniu nukenčia ịsivyravus karštiems ar šaltiems orams Lietuvoje. Prognozuojama, kad ateityje Lietuvoje karščio bangu gausės, o tai žmonèms sukels daug sveikatos problemų, nes pastatai nepritaikyti apsisaugoti nuo karščio bangu bei nėra irengta kondicionavimo sistemų (Kažys et al. 2008). Sumažejus šalčio bangų, mažiau žmonių patirs nušalimų, nukentès nelaimingų atsitikimų metu, ivvairių šalčio sukeliamų ligu komplikaciju (plaučių uždegimo, gripo) ar mirs nuo sušalimo. Tačiau manoma, kad tai greičiausiai nekompensuos to pavojaus, kuris numatomas žmonių sveikatai karščio bangų metu.

Egzistuoja ir tokių terminių indeksų, kurie gali būti taikomi įvertinant žmogaus juntamą temperatūrą išstisus metus (tiek šiltuoju, tiek šaltuoju metų lauku), tai - universalūs indeksai. Vienas iš populiariausių, plačiai žinomų ir labiausiai naudojamų - fiziologiškai ekvivalentinès temperatūros (PET) indeksas. Jis apibūdina terminès aplinkos poveikị žmogui (Matzarakis, Gulyas 2006) ir suvokiamas kaip tinkamos aprangos bei terminio komforto rezultatas, tiesiogiai susijęs su kūno ir aplinkos šilumos mainais (Höppe 1999).
PET prognozės Latvijoje jau yra teikiamos. Lietuvoje šis indeksas naudojamas tik moksliniais tikslais, norint atskleisti šio indekso reprezentatyvumą bei pritaikymo galimybes Lietuvos teritorijai. LHMT artimiausiu metu šias prognozes planuoja pradèti skelbti plačiajai visuomenei.

\section{Ultravioletinès spinduliuotės prognozė}

Pavojus sveikatai, i̇degimas ir odos vėžys sukelia žmonių domèjimąsi ultravioletinès spinduliuotès (UV) tyrimais. UV yra vienas iš aplinkos veiksnių, kuris turi labai didelę itaką žmogui. Nors ši itaka buvo žinoma jau daugeli metų (Riemerschmid 1938), tačiau labiau ja buvo susidomèta tik paskutiniais dešimtmečiais (Elwood, Jopson 1997; WMO 2002). Susidomèjimą sukèlè stratosferinio ozono sluoksnio plonėjimas, taip pat pastaraisiais dešimtmečiais išaugęs susirgimų odos vėžiu skaičius. Dèl tụ pačiu priežasčių kilo poreikis žmonèms suteikti daugiau informacijos apie UVI.

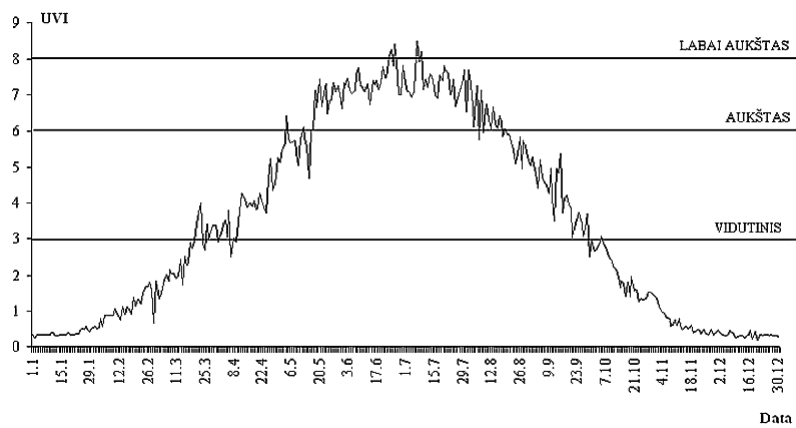

3 pav. Vidutinių maksimalių UVI reikšmių kaita Kaune 2001$2005 \mathrm{~m}$. ir UVI pavojingumo kategorijos

Fig. 3. Mean maximal UVI values in Kaunas in 2001-2005 and riskiness level

Lietuvoje UVI maksimalias reikšmes pasiekia birželio-liepos mėnesiais ( 3 pav.). Tačiau pavojingas jis tampa, kai UVI pasiekia 3. Tuo metu žemès paviršių pasiekęs UV kiekis jau gali sukelti įdegimą. Dažniausiai tai nutinka antroje kovo puseje ir išlieka iki spalio mènesio. Ši periodą skelbiama ir UVI prognozè. Ji sudaroma triju dienų laikotarpiui, informuoja apie UVI pavojingumo laipsni, tinkamą gyventojų fizini aktyvumą atvirame ore ir aprangos tipą bei kitas apsisaugojimo priemones.

Tikètina, kad ateityje UVB spinduliuotės kiekiai, pasiekiantys Lietuvos teritoriją, šiltuoju metų laiku didès, todèl būtina sukurti gyventojų informavimo apie kylančią grèsmę sistemą ir laiku teikti perspejimus bei rekomendacijas (Kažys et al. 2008). 


\section{Kitos biometeorologinès prognozès}

Oro užterštumo prognozès. Didèjant populiacijos tempams ir žmonių poreikiams, oro užterštumas tampa neatsiejama klimato kaitos proceso dalimi. Dèl didejjančio ozono kiekio priežeminiame oro sluoksnyje ar tiesiog nepalankių meteorologinių sąlygu teršalams sklaidytis ateityje oro užterštumas vis didès. O dažnesnès priežeminès temperatūrinès inversijos šiltuoju metų laiku lems padidèjusą oro taršą ir intensyvesnę alerginę reakciją. Tai turès poveiki padidintos rizikos žmonių grupès sveikatos būklès blogèjimui (IPCC 2001). Dèl oro kokybès prastèjimo jau padaugèjo ìvairių ligų: astmos, širdies nepakankamumo, plaučių vėžio ir daugelio kitų. Pasak Pasaulinès sveikatos organizacijos (WMO), dèl oro užterštumo kiekvienais metais miršta apie $2 \mathrm{mln}$. žmonių. Oro kokybès prognozès leidžia apsirūpinti būtinomis priemonėmis, o perspejjimai - sumažinti atmosferos užterštumo pavojų.

Šiuo metu Lietuvoje oro užterštumo prognozes skelbia Aplinkos apsaugos agentūra. Priklausomai nuo tam tikros teršalų koncentracijos ore, pateikiama gradacija, kaip žmonès turètų elgtis, kad išvengtų žalingo poveikio sveikatai.

Žiedadulkių kiekio ore prognozès. Šiltèjant klimatui, ilgèja vegetacijos laikotarpis ir įvairių augalų žydèjimo periodas, tad daugèja ir žiedadulkių (alergenų) kiekis ore. Nustatyta, kad gerai išsivysčiusiose valstybèse nuo žiedadulkių sukeltos alergijos kenčia apie $20 \%$ gyventojų, Lietuvoje kiek mažiau (Černiauskaitė 2006). Tikètina, kad ateityje dèl žiedadulkių sezono pailgejjimo padaugès ir joms alergiškų žmonių (ši tendencija pastebima jau dabar). Taip pat numatomas bronchinès astmos ir polinozès (šienligès) suaktyvejjimas.

Vilniaus, Klaipedos ir Šiaulių aerobiologinèse stotelèse vykdomas žiedadulkių koncentracijos ore monitoringas. Jų kiekiai priklauso nuo daugelio meteorologinių parametrų: oro temperatūros, debesuotumo, vejjo krypties ir greičio, kritulių ir pan. (Černiauskaitė 2006). Didelè žiedadulkių koncentracija susidaro nusistovèjus sausiems, karštiems ir saulètiems orams (Liukaitytė 2007) - tokios vasaros vyraus jau ši tūkstantmetị.

Lietuvoje žiedadulkių kiekio ore prognozès nèra sudaromos. Remiantis atliktais tyrimais, kad ateityje didèjant žiedadulkių koncentracijai ore, išaugs ir alergišku žmonių skaičius, šių prognozių sudarymas ir skelbimas bus būtinas, kad leistų lengviau susidoroti ar net išvengti alergijos simptomų.

Medicinines meteorologinès prognozès. Slègis, temperatūra bei drègmè yra svarbūs meteorologiniai parametrai, kurie turi itakos tiek fiziniams, tiek psichologi- niams žmonių susirgimams (Orgaz et al. 2002; Liukaitytė et al. 2008). Yra žinoma, kad staigūs orų pasikeitimai, slenkantys atmosferos frontai ar kiti orų pokyčiai daro pastebimą poveiki žmogaus sveikatai.

Šveicarijos meteorologijos tarnyba išskyrè svarbiausius atmosferos cirkuliacijų tipus, turinčius poveiki žmonių sveikatai. Ilgesniam laikui nusistovèjus aukšto slėgio sričiai, padidèja oro užterštumas, o tai sukelia kvėpavimo takų sutrikimų, plaučių ligų ir reumato paūmejjimų. Esant staigiems ar ne tokiems staigiems oru pasikeitimams, pakyla kraujospūdis, padažnėja epilepsijos priepuoliu, spazminių skausmų pasireiškia galvos skausmas ar apima depresija, padidèja miokardo infarktų (Liukaitytè et al. 2008). Žmonèms, jautriai reaguojantiems i orų pokyčius, dažnai reikalinga tam tikra terapija ar specialus režimas (Jendritzky, Bucher 1992). Todèl esamų ir būsimų orų sąlygų i̇vertinimas yra vienas iš medicininių meteorologinių prognozių tikslų.

Lietuvoje indèli i medicininę meteorologinę sritị i̇ejjo A. Martinkènas, V. Kaminskas ir G. Varoneckas, kurie $2007 \mathrm{~m}$. atliko Palangos pajūrio tyrimą, apimanti medicininių meteorologinių orų tipų ivertinimą bei empirinius prognozavimo modelius. Sudarytas medicininių meteorologinių klasių modelis leidžia tiksliau vertinti ir prognozuoti orus pagal juc palankumą (nepalankumą). Toks vertinimas gali pagelbėti mažinant oru itaką ligoniams, igyvendinant efektyvias meteoprofilaktikas ir panašiai (Martinkènas et al. 2007).

\section{Išvados}

1. Išankstinis visuomenès informavimas teikiant prognozes yra tinkama priemonè, padedanti prisitaikyti prie vykstančios klimato kaitos.

2. Norint sušvelninti ar visiškai išvengti neigiamo poveikio sveikatai, turi būti pradètos sudarinèti ir visuomenei skelbti biometeorologinès prognozès, kuriose būtú pateikiama informacija apie nepalankias sveikatai meteorologines sąlygas ar staigius oru pasikeitimus.

3. Šiuo metu Lietuvoje skelbiamos karščio indekso, vèjo žvarbumo, ultravioletinès spinduliuotès ir oro užterštumo prognozès.

4. Karščio sukeliamas diskomfortas jaučiamas 22$31 \%$ visų vasaros dienų. Maksimalios „Humidex“ indekso reikšmès Lietuvos teritorijoje fiksuojamos paskutinę liepos dekadą bei rugpjūčio pradžioje.

5. Lietuvoje UVI maksimalias reikšmes pasiekia birželio-liepos mėnesiais. Tačiau pavojingas jis tampa, kai UVI pasiekia 3. Dažniausiai tai nutinka antroje kovo pusèje ir išlieka iki spalio mėnesio. 
4. I Lietuvoje skelbiamų biometeorologiniu prognozių sąrašą itraukus ir kitas bometeorologines prognozes, prisitaikymas (ar apsisaugojimas) prie klimato kaitos būtų daug efektyvesnis.

\section{Literatūra}

Bukantis, A.; Šinkūnas, P.; Taločkaitė, E. 2007. Žmogaus sveikata. Klimato kaita: prisitaikymas prie jos poveikio Lietuvos pajūryje. Vilnius.

Černiauskaitè, V. 2006. Meteorologinių sąlygu itaka alnus, betula ir corylus žiedadulkiu sklaidai, iš Konferencijos ,Aplinka ir pasaulis " pranešimu santrauku rinkinys. Šiauliai, 12-13.

Dessai, S. 2002. Heat stress and mortality in Lisbon. Part I: model construction and validation, International Journal of Biometeorology 47(1): 6-12. doi:10.1007/s00484-002-0143-1

Elwood, M.; Jopson, J. 1997. Melanoma and sun exposure: an overview of published studies, Journal Cancer 73: 198203.

Epidemiology. 2008. Impact of and Adaption Extreme Weather Event in Changing Climate. ISEE 20th Annual Conference 19(6). Pasadena, California: Lippincott, Williams \& Wilkins.

Gosling, S. N.; McGregor, G. R.; Páldy, A. 2007. Climate change and heat-related mortality in six cities part I: model construction and validation, International Journal of Biometeorology 51(6): 525- 540. doi:10.1007/s00484-007-0092-9

Höppe, P. 1999. The physiological equivalent temperature - a universal index for the biometeorological assessment of the thermal environment, International Journal of Biometeorology 43: 71-75. doi:10.1007/s004840050118

IPCC. 2001. Climate Change 2001: Impacts, Adaptation, and Vulnerability. Contribution of Working Group II to the Third Assessment Report of the Intergovernmental Panel on Climate Change, Cambridge University Press.

Jendritzky, G.; Bucher, K. 1992. Medical-meteorological fundamentals and their utilization in Germany, in Proceedings of the Weather and Health Workshop 42-59.

Kažys, J.; Rimkus, E.; Liukaitytè, J. 2008. Globalios klimato kaitos poveikis žmogaus sveikatai, iš Biota ir globali kaita, I knyga, 91-106.

Kirch, W.; Menne, B.; Bertollini, R. 2005. Extreme Weather Events and Public Health Responses. Springer-Verlag. doi:10.1007/3-540-28862-7

Liukaityte, J. 2007. Žiedadulkiu kiekis ore artimiausiomis dienomis didès [žiūrèta $2009 \mathrm{~m}$. kovo 20 d.]. Prieiga per internetą: $<$ http://www.lrytas.1t/?id=11774475731175754280\& view $=4>$.

Liukaitytė, J.; Rimkus, E. 2008. Karštu orų keliamo terminio diskomforto Lietuvoje vertinimas, Geografija 2: 58-65.

Liukaitytè, J.; Savanevičius, J.; Rimkus, E. 2008. Atmosferos cirkuliacijos poveikio gyventojų sveikatos būklei Lietuvoje ivvertinimas, iš 11-oji Lietuvos jaunuju mokslininku konferencijos ,"Mokslas - Lietuvos ateitis “, ivykusios 2008 m. balandžio 3 d., straipsniu rinkinys. Vilnius: Technika, 65-72.

Martinkènas, A.; Kaminskas, V.; Varoneckas, G. 2007. Forecast model of impact of meteorological factors on coronary artery disease patients, Informatica 3: 407-418.
Massen, F. 2001. The New Windchill Formula. A Short Explanation [žiūrèta 2009 m. kovo 10 d.]. Prieiga per internetą: <http://www.restena.lu/meteo_lcd/papers/windchill/ newwindchill.html>.

Masterton J. M.; Richardson, F. A. 1979. A Method of Quantifying Human Discomfort due to Excessive Heat and Humidity. Environment Canada.

Matzarakis, A.; de Freitas, C.; Scott, D. 2004. Advances in Tourism Climatology. Freiburg.

Matzarakis, A.; Gulyas, A. 2006. A contribution to the thermal bioclimate of Hungary - mapping of physiologically equivalent temperature, Landscape, Environment and Society Studies 479-488.

McMichael, A. J., et al. 2003. Climate Change and Human Health - Risks and Responses. Campbell-Lendrum, World Health Organization (WHO).

Orgaz M. D. et al. 2002. Influence of Weather and Climate on Infectious Diseases. An Investigation in Aveiro Region [žiūrèta $2009 \mathrm{~m}$. kovo 3 d.]. Prieiga per internetą: $<$ http://www. iugg.org/members/nationalreports/portugal-iamas.pdf $>$.

Riederschmid, R. 1938. Zur Entwicklung der natuerlichen ultraviolettstrahlung, Radiologica 2: 126-137.

Sargent II, F. 1982. Hippocratic Heritage: a History of Ideas About Weather and Human Health. New York.

Unger, J. 1999. Comparisons of urban and rural bioclimatological conditions in the case of a Central-European city, International Journal of Biometeorology 43(3): 139-143. doi: $10.1007 / \mathrm{s} 004840050129$

VASC. 2009. Klimato kaita ir sveikata [žiūrèta $2009 \mathrm{~m}$. kovo 2 d.]. Prieiga per internetą: $<$ http://vasc.sam.lt/klimatas_ir_ sveikata.pdf $>$.

WHO. 2002. Global Solar UV index. A Practical Guide.

WHO. 2004. Heat-waves: risks and responses. Health and Global Environment Change 2.

WMO. 2004. Guidelines on Biometeorology and Air Quality Forecasts. $W M O / T D$ No. 1184

\section{BIOMETEOROLOGICAL FORECASTS AS ADAPTATION MEASURES IN THE CONTEST OF CLIMATE CHANGE}

\section{Nariūnaitė, J. Liukaitytė}

Summary

The basic aim of this paper is to review biometeorological forecasts in Lithuania as well as their necessities and adjustments toward climate change. Weather alterations and climate anomalies make a substantial impact on human health (physical and psychological), and therefore biometeorological forecasts are useful to foresee and elude some negative climate influence.

Keywords: biometeorological forecasts, climate change, adaptation. 